\title{
Boardroom female participation, intellectual capital efficiency and firm performance in developing countries \\ Evidence from Nigeria
}

Wakeel Atanda Isola Department of Economics, University of Lagos, Lagos, Nigeria

Bosede Ngozi Adeleye Department of Economics and Development Studies, Covenant University, Ota, Nigeria, and

Aminat Olayinka Olohunlana Department of Economics, University of Lagos, Lagos, Nigeria
Boardroom female participation

\begin{abstract}
Purpose - This paper aims to focus on the implications of female participation in the board on the management of intellectual capital for improved firm performance, particularly in the Nigerian-banking sector. It uses the resource dependency theory to ascertain the link between female board participation, intellectual capital and performances.

Design/methodology/approach - The paper adopted longitudinal panel analysis to analyze data obtained from the annual reports of selected listed commercial banks in Nigeria. The random effect regression was adopted as the method of analysis. The decision was informed by conducting the Hausman test.

Findings - The results revealed that female board participation has insignificant influence on bank performances, whereas intellectual capital efficiencies positively contribute to bank performances. However, significant influences were exhibited upon the interactions of female board participation and components of intellectual capital efficiency on bank performances.

Research limitations/implications - Because of the focus of the research work, which is centered on the banking sector of the Nigerian economy, the findings of the research may not be sufficiently suitable for other sectors of the country. This, however, leaves the coast for other researchers to extend research on intellectual capital and gender participation to other non-financial sectors and other countries.

Practical implications - The outcome implies that there is a need for increased female participation in the boardroom to harness optimal intellectual capital efficiencies for firm performance. It further confirmed that intellectual capital unlocks the hidden treasure of firms.
\end{abstract}

(C) Wakeel Atanda Isola, Bosede Ngozi Adeleye and Aminat Olayinka Olohunlana. Published in Journal of Economics, Finance and Administrative Science. Published by Emerald Publishing Limited. This article is published under the Creative Commons Attribution (CC BY 4.0) license. Anyone may reproduce, distribute, translate and create derivative works of this article (for both commercial and non-commercial purposes), subject to full attribution to the original publication and authors. The full terms of this license may be seen at http://creativecommons.org/licences/by/4.0/ legalcode

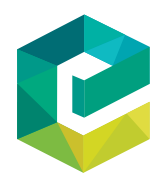

Journal of Economics, Finance and Administrative Science Vol. 25 No. 50,2020 pp. 413-424
Emerald Publishing Limited 2218-0648 DOI 10.1108/JEFAS-03-2019-0034 
JEFAS 25,50

Originality/value - The paper identifies and fulfills a niche on the need to extend the frontier of knowledge on intellectual capital and gender equity.

Keywords Nigeria, Intellectual Capital, Firm performance, Gender equity, Listed banks

Paper type Research paper

\section{4}

\section{Introduction}

Female participation in the boardroom in the past two decades has witnessed increasing attention among policymakers and the academia (Abdelzaher and Abdelzaher, 2019; Ahmad et al., 2018; Chiucchi et al., 2018; Moreno-Gómez et al., 2017; Mori, 2014), and to its credit, the volume of literature has grown significantly in the past one decade (Kilic and Kuzey, 2016; Moreno-Gómez et al., 2017; Singhatheep and Pholphirul, 2015). The growth is, however, not surprising because aside from the issues of gender discrimination and ethics, gender diversity is seen as having beneficial returns on firm performance (Maturo et al., 2019; Scholtz and Kieviet, 2017). Findings further reveal that more female participation in the boardroom increases human capital development because of the level of experiences and exposures taken onboard during decision-making (Mori, 2014).

The resource dependency theory of Pfeffer and Salancik (1978) noted that the opportunities available for the board members to harness and access resources is directly linked to the level of performance of the firm. The opportunities, however, could be fully explored if there are diverse avenues, which could be exhibited through the mixture in the composition of the board (AbdulKarem et al., 2015). Female representation on the board increases the opportunities for making strategic decisions that could increase a firm's competitive advantage (Ahmad et al., 2018). The skills, experiences and exposures attributed to the effective decision of the board members differ for men and women; hence, gender equity in the boardroom improves the level of harnessing firm resources that are rare and imitable (Abdelzaher and Abdelzaher, 2019).

Despite that the extant literature in developed nations attests to the increasing importance of gender mix (Kilic and Kuzey, 2016), little attention is given to its significance in developing and emerging countries (Ciftcia et al., 2019). Also, the few studies on the impact of female boardroom participation on a firm's performance exert mixed results. Scholtz and Kieviet (2017) revealed that female board participation enhances a firm's performance, whereas, on the contrary, Ahmad et al. (2018) and Manita et al. (2018) noted an insignificant impact. The reasons for the adduced negative impact of female board participation could be because of the limited number of female board members as well as inadequate use of the firm's intellectual resources to drive competitive advantage of women to improve performance (Chiucchi et al., 2018).

On the other hand, intellectual resources are capital inputs for firms that have the capacity to increase competitive advantage, growth and sustainability, especially in a knowledge-transiting economy (Nadeem et al., 2017). Intellectual capital because of its intangibility in usage is acclaimed as a hidden source of wealth creation for firms (Anifowose et al., 2017; Isola et al., 2017). This is because it encapsulates the human, structural and relational capitals of firms and the efficient use of each of this capital has umpteen beneficial effects on performance (Chiucchi et al., 2018). Hence, the capital resources possess unique value additions to the firm because of their rare and imitable nature. The optimal use of these resources can be directly attributed to the competence, skills, experience and diversity of the board of directors (Isola et al., 2017; Shettima and Dzolkarnaini, 2018). This is because they tend to make strategic decisions on the creation, usage and management of intellectual resources (Nadeem et al., 2017). In particular terms, female 
boardroom participation tends to contribute to the efficient and effective decision-making process, which has a positive effect on the optimal usage of intellectual capital and firm performance (Adams and Kirchmaier, 2016). However, the extant literature notes that the impact of board diversity in terms of female participation on intellectual capital is undermined despite its significance to firm performance (Mori, 2014).

This study situates Nigeria, an emerging economy and one of the economic powerhouses in sub-Saharan Africa, with a large concentration of industries, banks and corporate organizations. The observed identified gap in the industrial economics literature is the dearth of empirical evidence on the impact of female board participation on the efficient usage of intellectual capital vis-à-vis firm performance on emerging economies and the Nigerian-banking sector. Hence, this study fills this gap and attempts to establish the influence of female participation in the boardroom on the efficiency of intellectual capital as well as firm performance using 14 listed banks on the Nigerian Stock Exchange (NSE) from 2008 to 2017. The justifications for using the banking sector are diverse, namely, it is a very active component of the private sector and can proxy as being representative of corporate organizations, it employs an appreciable number of female staffs in different capacities and it was one of the worst-hit sectors during the 2008 global financial crisis because of weak corporate governance, which had since been improved upon. Given these, Nigeria's banking sector is attractive for the investigation of the implications of female board participation in the efficient usage of intellectual capital resources for firm performance. Added to the highlighted reasons, the sector is one of those that require a critical assessment of its intellectual capital optimal usage because of the intangibility of the products and services it offers.

Therefore, this study's objectives are as follows:

- to evaluate the impact of female participation on firm performance;

- to establish the link between intellectual capital and firm performance; and

- to investigate the interactive influence of female board participation and intellectual capital efficiency on firm performance, for which the econometric techniques of the random effects (RE) model are used.

Also, two measures of firm performance are used, which are return on assets (ROA) and return on equity (ROE). Similarly, the study follows Pulic's (2000) measure of value-added intellectual capital (VAIC) and Moreno-Gómez et al.'s (2017) measure of female board participation. The policy relevance of this study is not far-fetched. For one, it will bring to light the issue of gender-biasedness and inequality in the corporate world and highlight the need to give the female gender some proportionate representation in boardroom decisionmaking. The rest of the study is structured as follows: Section 2 gives a brief literature review, Section 3 details the data and empirical model and results are discussed in Section 4, while Section 5 concludes with policy implications.

\section{Brief literature review}

Several theories have established the connection between female participation in the boardroom and firm performance, among which are the upper echelons theory (AbdulKarem et al., 2015), the critical mass theory (Moreno-Gómez et al., 2017), the social identity agency theory (Mori, 2014) and the resource-based theory (Ahmad et al., 2018). This study, however, adopts the resource-based theory because it takes cognizance of the need to develop and use internal resources (intellectual capital) through board decisions, which could be more robust given equity in gender representation (Hsu et al., 2018).

\section{Boardroom female participation}


JEFAS

25,50

416
The boardroom is noted to be an environment where the central activities of an organization are strategically decided upon, controlled and monitored for growth and survival (Agyei-Mensah, 2018; Moreno-Gómez et al., 2017). The boardroom itself cannot judiciously perform without a league of highly diverse, innovative and strategic members, whose main function is to deliver outstanding performance to the shareholders (Hickman, 2014; Klettner et al., 2016). Extant studies on board performance, as measured by its diversity in the developed regions exhibited strong and positive implications on firm value (Hsu et al., 2018). Most of these studies, however, find a significant relationship between female participation and firm performance (Klettner et al., 2016). This could be attributed to the degree of skills and experience that the women on the board exhibited in the decisionmaking process.

However, not until recently, developing countries are now giving significant attention to the impact of female board participation on the growth and survival of firms (Mori, 2014). Given these, findings from developing countries are inconclusive as some studies (Joecks et al., 2013; Moreno-Gómez et al., 2017) depict positive implications of female board participation on the board. These affirm the assertions that quality corporate governance in terms of diverse usage among board members is often reflected in firms' improved performance. Contrarily, some scholars (Abdulkarem et al., 2015; Shettima and Dzolkarnaini, 2018) noted that the degree of diversity of board members can be directly ascribed to firms' low performance because of the timeliness in resolving intellectual argument. More views and strands support the need for high heterogeneity in board gender composition owing to the dominance of diverse knowledge stock and enhanced qualitative decision-making.

Likewise, the significance of board diversity to the improvement of firm performance cannot be overemphasized, and board diversity has been measured in diverse manners. Some studies used an index with the numerous measures of diversity such as age, tenure, nationality, ethnicity and gender composition to represent the variable. Nonetheless, it is of utmost importance to evaluate the individual implications of these measures on firm performance. Studies by Moreno-Gómez, Lafuente and Vaillant (2017) evaluated the significance of gender equity in the composition of the board and top executive management. The study revealed that there exists a positive relationship between female top management staff and corporate performance measured by the ROE. In a related manner, Abdelzaher and Abdelzaher (2019) established a positive link between the women represented on board and the performances of the firms in Egypt, whereas AbdulKarem et al. (2015) established the impact of gender diversity and the mediating influence of board effectiveness on firm performance. Their findings reveal that intellectual capital efficiency increases as the mediating influence of board meeting increases.

\section{Data and model}

The study uses a panel data of 14 banks listed on the NSE from 2008 to 2017. The licenses of all listed banks are categorized into three, based on the commercial banking licensing regulations enacted in 2010. The categories of licenses issued are international, regional and national. Thus, this study focuses on commercial banks with national and international licenses. Out of the 19 banks with national and international authorization, 14 are selected because of the adequacy and availability of financial information.

\subsection{Data and sources}

The variables used in this study are sourced from the annual reports of the banks obtained from their respective websites, the NSE Portal and the African Markets website. The 
dependent variable is firm performance (proxied by ROA and ROE), whereas the independent variables are the female board participation and intellectual capital. This paper follows similar studies for the measures used in defining these variables, which are explained in the following text:

Firm performance: The first proxy used is the ROA, which measures the economic performance of the firm. It is defined as the proportion of the net income to total assets and expressed as:

$$
R O A=\frac{\text { Gross revenue }- \text { Total operating expenses }}{\text { Total assets }}
$$

The second proxy is the ROE, which measures financial performance. It is calculated as the proportion of net income to the total equity of the firm and expressed as follows:

$$
R O E=\frac{\text { Gross revenue }- \text { Total operating expenses }}{\text { Total shareholder's equity }}
$$

Boardroom female participation (BFP): Following Moreno-Gómez et al. (2017), this measures the proportion of female board members to the total board members derived:

$$
\text { BFP }=\frac{\text { Total of female board members }}{\text { Board size }}
$$

Intellectual capital efficiency: This variable explains the variations between the book and market value of a firm (Isola et al., 2017). It depicts the source of competitive advantage and wealth creation of firms. The efficiency of intellectual capital is often measured in some ways, but the most prominent and widely acceptable measure is the Pulic (2000) measure of intellectual capital. Pulic's VAIC is noted by many scholars as the most appropriate because of the usage of data from the company's performance rather than the subjective measurement approach (Isola et al., 2017). Hence, this measure is adopted because of its quantitative measurement approach. The VAIC is the composition of the human, structural and the capital employed of the firm expressed as:

$$
V A I C=H C E+S C E+C C E
$$

The human capital efficiency $(H C E)$ is measured as the proportion of the firm's value addition attributable to the investment on human capital, efficiency in the firm's structural capital efficiency $(S C E)$ is measured as the variations between the company's value-added and its investment on human capital and the firm's value-added capital employed efficiency $(C E E)$ is the summation of the operating profit $(O P)$, employee costs $(E C)$, amortization $(A)$ and firm depreciation $(D)$. Hence, value-added $(V A)$ is given as follows:

$$
V A=O P+E C+A+D
$$

And by expansion, the VAIC is expressed as:

$$
V A I C=\frac{H C}{V A}+\frac{V A}{S C}+\frac{C E}{V A}
$$

where $H C$ is the expenses on employee, $E C$ is the stock of equity capital and $S C$ is $V A-H C$. This study adopts the VAIC measure of intellectual capital but focuses on the implications of its individual components on firm performance. 
JEFAS 25,50

418

Control variables: In line with similar studies (Abdelzaher and Abdelzaher, 2019; Hsu et al., 2018; Shettima and Dzolkarnaini, 2018), variables that can influence firm performance are controlled for. These are bank size, bank age, board independence and director shareholding structure. Bank size is measured by the natural logarithm of total assets, bank age is measured by the year of incorporation of the bank, board independence is measured by the proportion of the independent directors to board size and the proportion of directors' shareholding to the total shares measures the director's shareholding structure.

\subsection{Empirical model}

The use of a longitudinal panel data set is consistent with previous studies (Chiucchi et al, 2018) because it combines the characteristics of time series and cross-sectional data. Ciftcia et al. (2019) noted that the Hausman test is the most widely used panel data specification test to select the most appropriate estimation technique. The test compares the RE estimator to the "within" estimator (fixed effects). If the null hypothesis that the random effects are independent of explanatory variables is rejected, this favors the "within" estimator's treatment of the omitted effects. The use of the test, in this case, is to discriminate between a model where the omitted heterogeneity is treated as fixed and correlated with the explanatory variables and a model where the omitted heterogeneity is treated as random and independent of the regressors. The significance of the $p$-value of the test statistic is used to justify the use of the fixed effects over the RE estimator. In this study, however, the outcome of the Hausman test as given by the test statistic of 0.8743 supports the use of the RE model because of our inability to reject the null hypothesis. Following Abdelzaher and Abdelzaher (2019), the empirical model is modified as follows:

$$
\begin{aligned}
F P_{i t}= & \alpha_{0}+\alpha_{1} \mathrm{FBP}_{i t}+\alpha_{2} \mathrm{HCE}_{i t}+\alpha_{3} \mathrm{CCE}_{i t}+\alpha_{4} \mathrm{SCE}_{i t}+\alpha_{5}(\mathrm{FBP} * \mathrm{HCE})_{i t} \\
& +\alpha_{6}(\mathrm{FBP} * \mathrm{CCE})_{i t}+\alpha_{7}(\mathrm{FBP} * \mathrm{SCE})_{i t}+\varepsilon
\end{aligned}
$$

where $F P_{i t}$, the measure of firm performance is measured by ROE and ROA, $\alpha_{0}$ is the constant term, $\alpha_{1}$ to $\alpha_{7}$ represent the parameters to be estimated, and $i$ and $t$ are the number of firms and time, respectively, while $\varepsilon$ stands for the disturbance term. Using ROA and $\mathrm{ROE}$ as alternating dependent variables, equation (7) is estimated sequentially. First, the nexus of female participation and firm performance is analyzed, followed by components of intellectual capital and firm performance and lastly the interactive influence of female board participation and intellectual capital efficiency on firm performance.

\section{Empirical results and discussions}

\subsection{Correlation analysis and summary statistics}

The summary statistics indicate that the average rate of ROA is 2.39 per cent, with the least negative return of -6.38 per cent and a wide variation of 5.02 per cent from the mean value. This is indicative that the ROAs have a wide differential across banks. The banking sector average ROE of 15.32 per cent for the period under review while a wide variation in the ROE is observed. In terms of female participation in the boardroom, average female participation is 15 per cent; the highest rate of female board members to the total board member is 40 per cent, while there are some firms with zero female board members (Table I).

The HCE in terms of the sector's value-added output had a maximum ratio of 9.5, the least ratio was 0.01 and the mean value stood at 2.91. This indicated that many banks exhibit lesser efficiency level in terms of human capital usage. Similarly, the CEE exhibited the same minimum returns to the value-added, while the maximum efficiency ratio was 5.53 , the mean efficiency capital employed ratio was 0.43 . This indicated that human capital is 


\begin{tabular}{|c|c|c|c|c|c|c|}
\hline Variables & Mean & SD & Minimum & Maximum & Observations & oardroom \\
\hline ROA & 2.39 & 5.02 & -6.38 & 53.12 & 140 & ation \\
\hline ROE & 15.32 & 71.62 & -36.61 & 631.91 & 140 & \\
\hline Female board participation & 15.75 & 10.57 & 0 & 40 & 140 & \\
\hline $\mathrm{HCE}$ & 2.91 & 1.72 & 0.01 & 9.5 & 140 & \\
\hline SCE & -0.82 & 9.55 & -99.4 & 0.9 & 140 & \\
\hline Capital employed efficiency & 0.43 & 0.57 & 0.01 & 5.53 & 140 & 419 \\
\hline Firm size & 8.97 & 0.38 & 8.05 & 9.72 & 140 & \\
\hline Director shareholdings & 0.03 & 0.08 & 0 & 0.91 & 140 & \\
\hline Board size & 14.69 & 2.93 & 7 & 22 & 140 & \\
\hline Firm age & 15.57 & 12.19 & 1 & 47 & 140 & \\
\hline Ownership concentration & 82.57 & 12.32 & 56.4 & 98.9 & 140 & able I \\
\hline \multicolumn{6}{|c|}{ Source: Authors' computation, 2019} & Summary statistics \\
\hline
\end{tabular}

better used than capital employed. SCE in a different vein recorded the least efficiency ratio. This reflected that the processes of the banks need to be improved for better and optimal usage.

Table II presents the correlation analysis of the variables used in the model. The table shows the degree of association among the variables. The result provides evidence of a very high degree of correlation (0.85) between the ROA and ROE. However, this outcome poses no econometric problem, as both serve as alternating dependent variables. All other variables exhibit mild correlations, hence, the problem of multicollinearity is circumvented.

\subsection{Empirical results}

In Tables III and IV, the results of the regression analysis are shown when ROE and ROA are used interchangeably as dependent variables and Columns A to E relate to the five systematic estimations of equation (7). Column A details the findings of the female board and firm performance nexus, which reveal that female board participation does not have any statistically significant impact on firm performance. This suggests that there is no evidence to support the hypothesis that increasing the number of female boardroom participants enhances firm performance. This outcome can be attributed to the minority composition of female board members, and as such, their influence will largely be unfelt on the

\begin{tabular}{|c|c|c|c|c|c|c|c|c|c|c|c|c|c|}
\hline \multicolumn{2}{|l|}{ Description of variables } & (a) & \multirow[t]{2}{*}{ (b) } & \multirow[t]{2}{*}{ (c) } & \multirow[t]{2}{*}{ (d) } & \multirow[t]{2}{*}{ (e) } & \multirow[t]{2}{*}{ (f) } & \multirow[t]{2}{*}{ (g) } & \multirow[t]{2}{*}{ (h) } & \multicolumn{3}{|c|}{ (i) (j) $(\mathrm{k})$} & \\
\hline ROA & (a) & 1 & & & & & & & & & & & \\
\hline ROE & (b) & 0.85 & 1 & & & & & & & & & & \\
\hline Female board participation & (c) & 0.16 & -0.07 & 1 & & & & & & & & & \\
\hline $\mathrm{HCE}$ & (d) & 0.39 & 0.32 & 0.29 & 1 & & & & & & & & \\
\hline SCE & (e) & 0.02 & 0.03 & 0.16 & 0.26 & 1 & & & & & & & \\
\hline Capital employed efficiency & (f) & 0.63 & 0.4 & -0.12 & 0.28 & 0.11 & 1 & & & & & & \\
\hline Firm size & (g) & -0.17 & -0.1 & 0.34 & 0.5 & 0.31 & -0.21 & 1 & & & & & \\
\hline Director shareholdings & (h) & 0.03 & 0.04 & -0.02 & -0.09 & 0.01 & -0.04 & -0.09 & 1 & & & & Table II \\
\hline Board size & (i) & -0.23 & -0.18 & 0.05 & 0.02 & 0.16 & -0.18 & 0.33 & 0.22 & 1 & & & 1 abie in: \\
\hline Firm age & (j) & -0.03 & -0.07 & 0.08 & 0.13 & 0.03 & 0.04 & 0.17 & -0.15 & 0.37 & 1 & & Source: Authors \\
\hline Ownership concentration & (k) & -0.19 & -0.07 & 0.1 & -0.4 & -0.01 & -0.16 & -0.31 & 0.12 & 0.08 & 0.3 & 1 & $\begin{array}{l}\text { computation, } \\
\text { 2019Correlation }\end{array}$ \\
\hline Source: Authors' computat & ions & & & & & & & & & & & & analysis \\
\hline
\end{tabular}


JEFAS

25,50

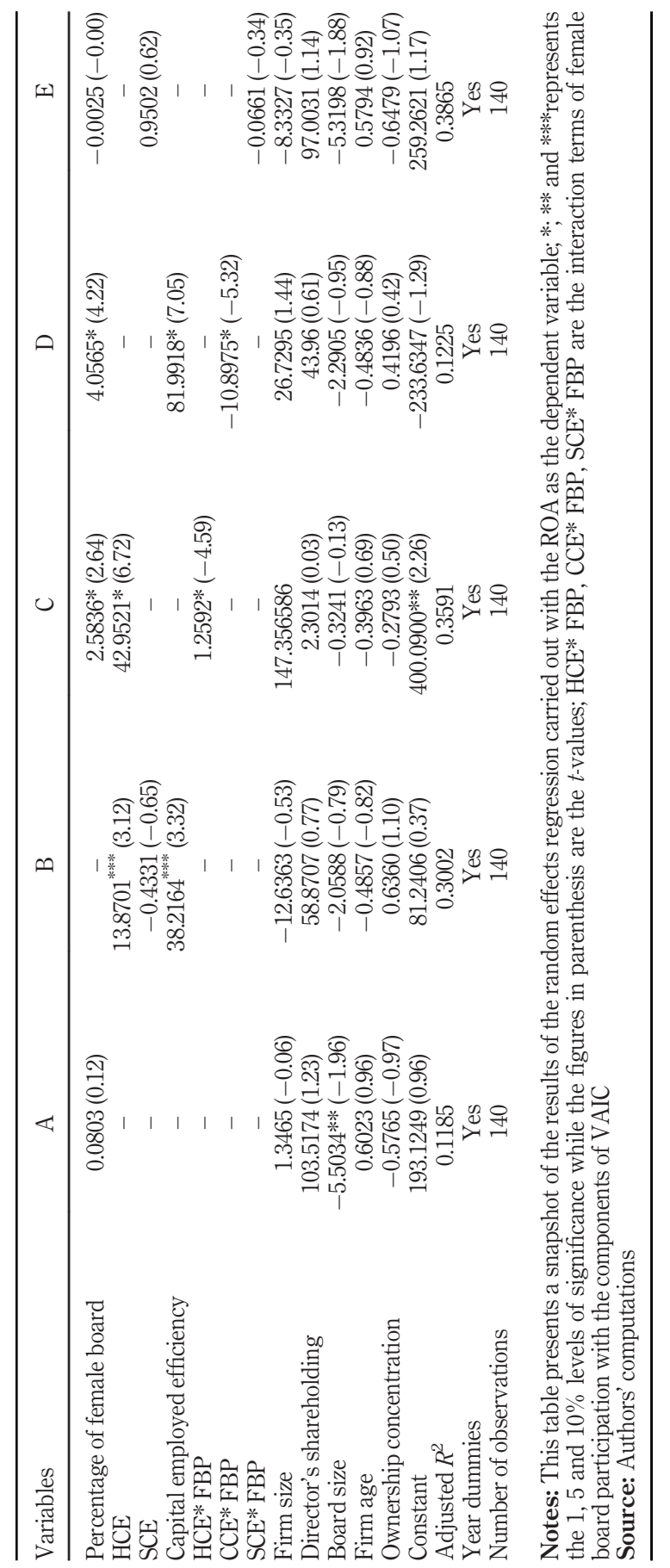

Table III.

Empirical results

(dep. variable: ROE) 


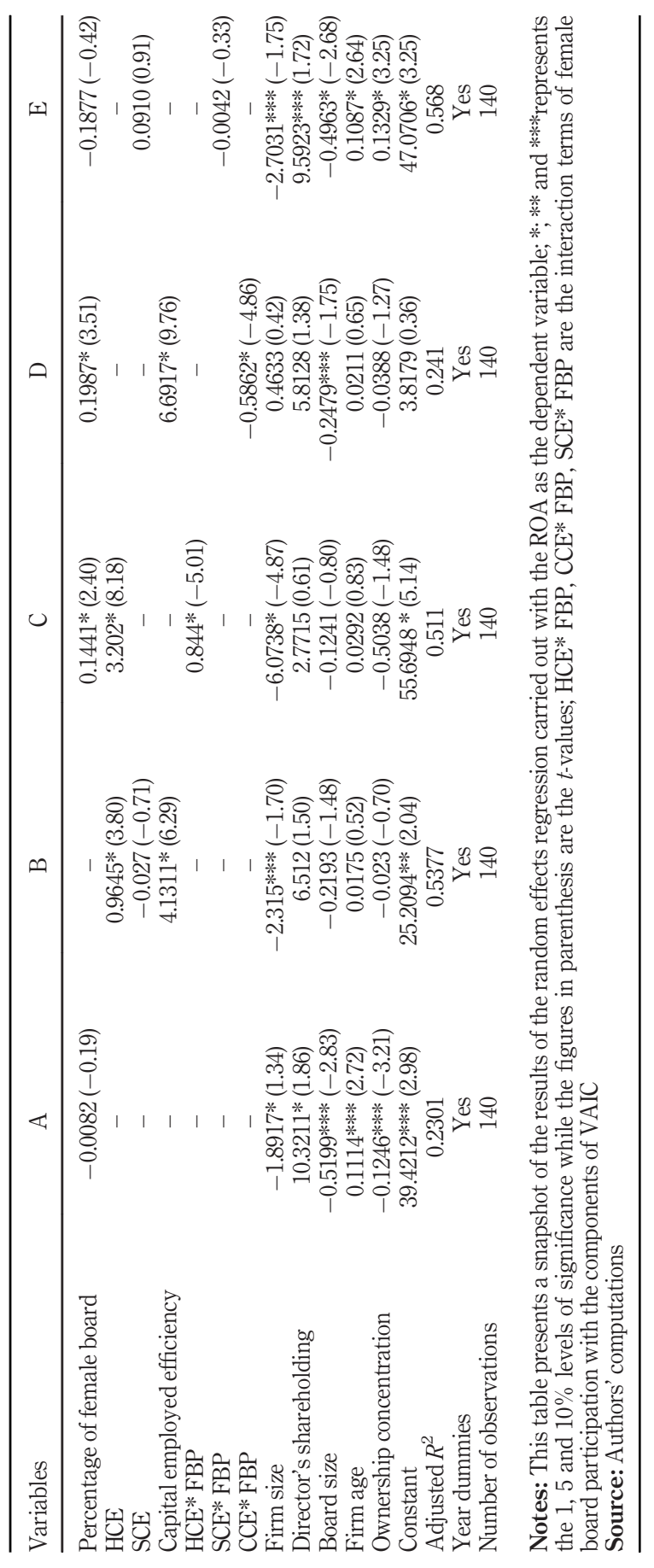

Table IV. Empirical results (dep. variable: ROA) 
JEFAS 25,50

performances of the firm. These findings contradict the works of Scholtz and Kieviet (2017) but align with those of Ahmad et al. (2018), Shettima and Dzolkarnaini (2018) and Manita et al. (2018). Ahmad et al. (2018) show that the presence of female board members is not significant to boost firm performance in terms of corporate social responsibilities, while Manita et al. (2018) posit the same findings in terms of the link between gender diversity and environmental, social and governance disclosures. Similar arguments for Column A are presented in Table IV.

Column B details the outcome of the relationship between the ROE and VAIC components (human capital, structural capital and capital employed). The results reveal that a significant and positive relationship exists between human capital, capital employed and the ROE. These outcomes lend support to those obtained by Anifowose et al. (2017), which confirm that HCEs have positive and significant contributions toward firm performance. The structural capital, on the contrary, exhibits an insignificant connection with the ROE and this conforms with the study conducted by Nadeem et al. (2017). The insignificance may be connected with the mode of measurement and likely measurement errors. It could also be that the banks are not exploring enough innovative ideas on product development as well as not having sufficient skills or processes to drive innovative ideas. A similar outcome is noted when the ROA is used as a dependent variable in Column B of Table IV.

Likewise, Column $\mathrm{C}$ of Table III expresses the outcome of the functional relationship between the interactions of female board participation and HCE on performances of the listed banks. The results reveal that upon interaction, both human capital and female boardroom participation reflect a positive and significant effect on firm performance. This indicates that female participation has an indirect significant effect on the performances of the firms when HCEs are fully explored. In fact, the significance level improved from the initial 10 per cent to 1 per cent. Also, Column C of Table IV shows an exact comparable outcome when the ROA is adopted as a proxy for firm performance. Examining the outcome of the interactions of capital employed and female boardroom participation results in Column D of Table III that show a significant influence of female participation and capital used on the ROE. A similar outcome is noted on the returns on capital as indicated in Column D of Table IV.

On the contrary, Column E of Table III details an insignificant effect of the interactions of structural capital and female participation in the board. This outcome is like the result of the study by Abdulkarem et al. (2015), who examine the interactions of intellectual capital efficiencies and board effectiveness on firm performance. The results suggest that the female participation on board needs to be strengthened and the females on board should possess relevant skills, educational background and professional certifications that relate to the activities in the banking sector.

Controlling for other factors that influence the performance of the firm, director shareholding and firm age as a year of the listing has significant influences on the performances of listed commercial banks in Nigeria. This depicts that the stake of directors on board mounts pressures on them on their performance to improve the firm's performance; however, this might likely impose a greater risk and volatility especially upon retirement, when directors seek to withdraw their funds. The number of years of incorporation of the banks, on the other hand, improves its performance because that is the period when most of its reports become public and is influenced by the investor's decision. Ownership concentration reveals a negative but significant relationship with firm performance. This result conforms to those of Chiucchi et al. (2018) and Ciftcia et al. (2019). It is indicative that a high ownership concentration influences the decisions on the board and may hamper firm performance. 


\section{Policy implications and conclusion}

This study examines the nexus of female board participation, intellectual capital and firm performance in Nigeria using a panel data set of 14 listed banks on the NSE from 2008 to 2017 analyzed using the RE estimation technique. Notable contributions made to the industrial economics literature show that intellectual capital significantly contributes to firm performance. Optimal intellectual capital usage brings about competitive advantages, creates value addition as well as attracts domestic and foreign investment. In retrospect, even though the impact of female participation is not statistically significant, our findings tilt toward the encouragement of female participation in the boardroom, as it has been revealed that women are better drivers on intellectual capital efficiencies of firms, which were revealed when the intellectual capital components interacted with female participation in the board. Furthermore, adequate female representation in the board increases the impact of human and capital employed efficiencies in the value addition process of the firms. Policy recommendations to corporate organizations suggest that a more attentive culture needs to be developed on the potential benefits accrued to having more females on their boards. The outcomes of this research have relevant policy implications for gender equity experts, policymakers and academia. Gender equity and diversity having been acknowledged as an important driver of the company's intellectual resources, which in turn drives its corporate performance. This paper contributes to the better comprehension of the impact of female participation in the boardroom on the performances of the banks in Nigeria. Policymakers should encourage more female participation to maximize the likely economic gains that will accrue as a result of such participation on the board.

\section{References}

Abdelzaher, A. and Abdelzaher, D. (2019), "Women on boards and firm performance in Egypt: post the Arab spring”, The Journal of Developing Areas, Vol. 53 No. 1, pp. 225-241.

Abdulkarem, M., Al-Musali, M. and Ismail, K.N. (2015), "Board diversity and intellectual capital performance: the moderating role of board effectiveness", Accounting Research Journal, Vol. 28 No. 3, pp. 268-283.

Adams, R. and Kirchmaier, T. (2016), "Women on board in finance and STEM industries", American Economic Review, Vol. 106 No. 5, pp. 1-6.

Agyei-Mensah, B. (2018), "Impact of corporate governance attributes and financial reporting lag on corporate financial performance", African Journal of Economic and Management Studies, Vol. 9 No. 3, available at: https://doi.org/10.1108/AJEMS-08-2017-0205

Ahmad, N., Rashid, A. and Gow, J. (2018), "Corporate board gender diversity and corporate social responsibility reporting in Malaysia", Gender, Technology and Development, pp. 1-23, doi: 10.1080/09718524.2018.1496671.

Anifowose, M., Abdul Rashid, M.H. and Annuar, H.A. (2017), "Intellectual capital disclosure and corporate market value: does board diversity matter?", Journal of Accounting in Emerging Economies, Vol. 7 No. 3, pp. 369-398.

Chiucchi, M.S., Giuliani, M. and Poli, S. (2018), "The relationship between intellectual capital performance and ownership gender diversity in small-sized Italian companies", in Paoloni and Lombardi (Eds), Gender Issues in Business and Economics, Proceedings in Business and Economics, Springer, pp. 67-71.

Ciftcia, I., Tatoglu, E., Wood, G., Demirbag, M. and Zaimd, S. (2019), "Corporate governance and firm performance in emerging markets: evidence from Turkey", International Business Review, Vol. 28 No. 1, pp. 90-103.

Hickman, E. (2014), "Boardroom gender diversity: a behavioral economics analysis", Journal of Corporate Law Studies, Vol. 14 No. 2, pp. 385-419, doi: 10.5235/14735970.14.2.385.
Boardroom female participation

423 
JEFAS 25,50

Hsu, C., Lai, W. and Yen, S. (2018), "Boardroom diversity and operating performance: the moderating effect of strategic change", Emerging Markets Finance and Trade, pp. 1-28, doi: 10.1080/ 1540496X.2018.1519414.

Isola, W.A., Odekunle, L.A. and Akanni, L.O. (2017), "Intellectual capital and firm performance: a review of empirical literature based on VAIC ${ }^{T M}$ model", Unilag Journal of Humanities, Vol. 5 No. 1, pp. 49-65.

Joecks, J., Pull, K. and Vetter, K. (2013), "Gender diversity in the boardroom and firm performance: What exactly constitutes a "critical mass", Journal of Business Ethics, Vol. 118 No. 1, pp. 61-72.

Kilic, M. and Kuzey, C. (2016), "The effect of board gender diversity on firm performance: evidence from Turkey", Gender in Management: An International Journal, Vol. 31 No. 7, pp. 434-455.

Klettner, A., Clarke, T. and Boersma, M. (2016), "Strategic and regulatory approaches to increasing women in leadership: multilevel targets and mandatory quotas as levers for cultural change", Journal of Business Ethics, Vol. 133 No. 3, pp. 395-419.

Manita, R., Bruna, M.G., Dang, R. and Houanti, L. (2018), "Board gender diversity and ESG disclosure: evidence from the USA", Journal of Applied Accounting Research, Vol. 19 No. 2, pp. 206-224.

Maturo, F., Migliori, S. and Paolone, F. (2019), "Nationality board diversity in organizations: a brief review and future research directions", in Flaut, C., Hoskova-Mayerova, S. and Flaut, D. (Eds), Models and Theories in Social Systems, Studies in Systems, Decision and Control, Switzerland, available at: https://doi.org/10.1007/978-3-030-00084-4_3

Moreno-Gómez, J., Lafuente, E. and Vaillant, Y. (2017), "Gender diversity in the board, women leadership and business performance", Gender in Management: An International Journal, doi: 10.1108/GM-05-2017-0058.

Mori, N. (2014), "Directors' diversity and board performance: evidence from East African microfinance institutions", Journal of African Business, Vol. 15 No. 2, pp. 100-113.

Nadeem, M., Gan, C. and Nguyen, C. (2017), "The importance of intellectual capital for firm performance: evidence from Australia”, Australian Accounting Review, pp. 1-11, doi: 10.1111/ auar.12184.

Pfeffer, J. and Salancik, G.R. (1978), The External Control of Organizations: A Resource Dependence Perspective, Harper Row, New York, NY.

Pulic, A. (2000), "VAIC ${ }^{\text {TM }}$-an accounting tool for IC management", International Journal of Technology Management, Vol. 20 Nos 5/6/7/8, pp. 702-714.

Scholtz, H. and Kieviet, S. (2017), "The influence of board diversity on company performance of South African companies", Journal of A frican Business, pp. 1-20, doi: 10.1080/15228916.2017.1356065.

Shettima, U. and Dzolkarnaini, N. (2018), "Board characteristics and microfinance institutions' performance: panel data evidence from Nigeria", Journal of Accounting in Emerging Economies, available at: https://doi.org/10.1108/JAEE-01-2017-0006

Singhatheep, T. and Pholphirul, P. (2015), "Female CEOs, firm performance, and firm development: evidence from Thai manufacturers", Gender, Technology and Development, Vol. 19 No. 3, pp. $320-345$.

\section{Corresponding author}

Aminat Olayinka Olohunlana can be contacted at: eniayewuyinka@yahoo.com

For instructions on how to order reprints of this article, please visit our website:

www.emeraldgrouppublishing.com/licensing/reprints.htm

Or contact us for further details: permissions@emeraldinsight.com 